\title{
3-(1-Cyclohexylpyrrolidin-2-ylidene)-3H-indole and 4-(cyclohexylamino)-1-(1H-indol-3-yl)butan-1-one - the balance between enaminimine and ring-opened forms
}

\author{
Masomeh Aghazadeh, ${ }^{c}$ James Raftery, ${ }^{\text {b }}$ Mehdi M. Baradarani, ${ }^{* a}$ and John A. Joule ${ }^{\text {b }}$ \\ ${ }^{a}$ Department of Chemistry, Faculty of Science, University of Urmia, Urmia, 57153-165, Iran \\ ${ }^{\mathrm{b}}$ The School of Chemistry, The University of Manchester, Manchester M13 9PL, UK \\ c Islamic Azad University, Maku Branch, Maku, Iran \\ E-mail: mmbaradarani@yahoo.com
}

For the $65^{\text {th }}$ anniversary of Professor Keith Smith a one-time tutee of one (JAJ) of the authors - didn't he do well!

DOI: $\underline{\text { http://dx.doi.org/10.3998/ark.5550190.0013.710 }}$

\begin{abstract}
Reaction of indole with the combination 1-cyclohexyl-2-pyrrolidinone and phosphoric trichloride gives the hydrochloride of 3-(1-cyclohexylpyrrolidin-2-ylidene)-3H-indole. Treatment of this with base at room temperature causes hydrolytic ring opening producing 4(cyclohexylamino)-1-(1H-indol-3-yl)butan-1-one but careful low-temperature basification allows the isolation of 3-(1-cyclohexylpyrrolidin-2-ylidene)-3H-indole itself. The crystal structure of the hydrochloride, as a dihydrate, was determined.
\end{abstract}

Keywords: Indole, Vilsmeier, indolenine, $3 H$-indole, $X$-ray crystallography

\section{Introduction}

The reaction of indole with the Vilsmeier reagent ${ }^{1}$ (formed using $N, N$-dimethylformamide (DMF) and phosphoric trichloride), followed by base, is the classic, and very efficient, method for the 3-formylation of indoles ${ }^{2}$ (e.g. $\rightarrow$ 2, Scheme 1) and indeed other electron-rich heterocycles. ${ }^{3}$ Before the alkaline hydrolysis step, the product is a salt, 3[(dimethylamino)methylene]-3H-indolium chloride (1) to which hydroxide adds then dimethylamine is lost revealing the aldehyde. Ketones can also be obtained in this way, using $N, N$-dimethylamides of acids other than formic. ${ }^{4}$ 


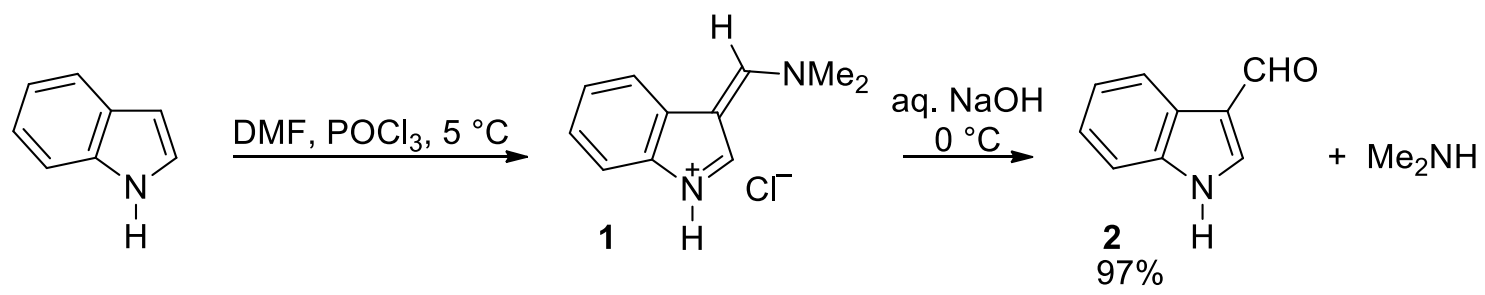

\section{Scheme 1}

Secondary cyclic amides can also be utilized but interestingly, the products do not hydrolyze to give a ketone, but remain ring-closed, as an imine, thus for example from pyrrole and 2pyrrolidinone, 2-(3,4-dihydro-2 $H$-pyrrol-5-yl)- $1 H$-pyrrole (3) is obtained (Scheme 2). ${ }^{5}$ Comparable 7-(3,4-dihydro-2H-pyrrol-5-yl)- $1 H$-indoles can be similarly obtained, 4,6dimethoxyindoles being susceptible to electrophilic attack at C-7. ${ }^{6}$ 3-(3,4-Dihydro- $2 \mathrm{H}$-pyrrol-5yl)- $1 H$-indole (4), prepared by a different method, also adopts a ring-closed form. ${ }^{7}$

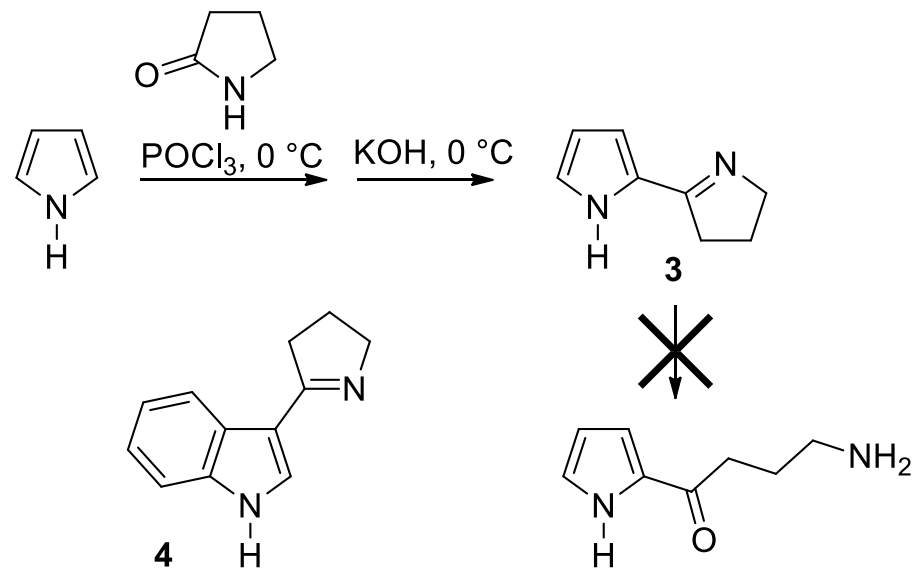

\section{Scheme 2}

When the tertiary cyclic amide 1-methyl-2-pyrrolidinone is utilized under Vilsmeier conditions with indole, 3-(1-methylpyrrolidin-2-ylidene)-3H-indole (5) is the product after base treatment - despite the loss of pyrrole ring aromaticity, the system does not hydrolyze to the amino-ketone (6) (Scheme 3). However, when 1-methyl-2-piperidinone is used as the amide, hydrolysis does occur and the isolated product is 1-(1H-indol-3-yl)-5-(methylamino)pentan-1one (7). ${ }^{8}$ It is clear that the relative stabilities of a 3 -(dialkylaminomethylene)- $3 H$-indole structure and its corresponding amino-ketone, are delicately balanced. 


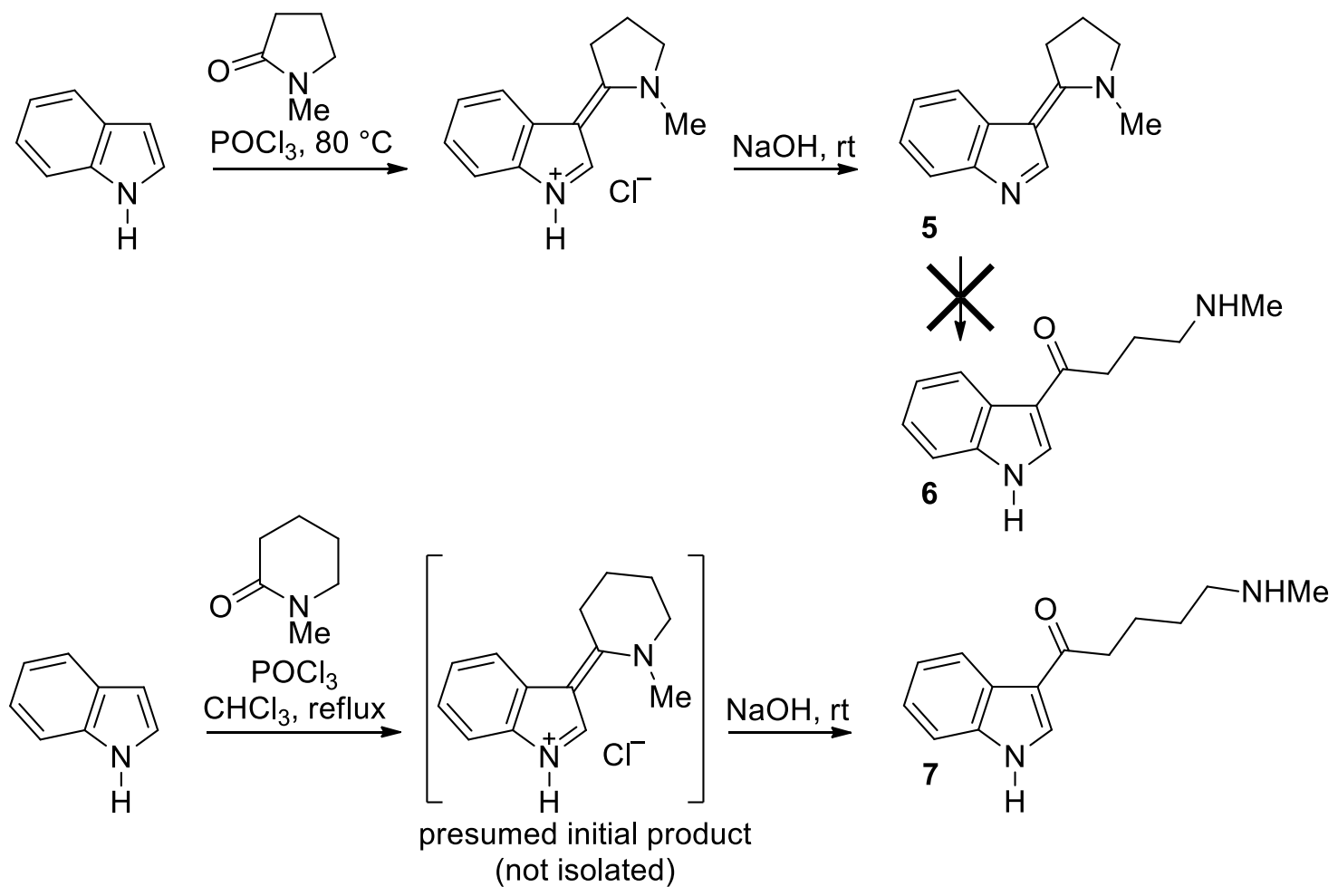

Scheme 3

\section{Results and Discussion}

We have expended considerable and rewarding efforts on investigations of the properties and reactions of 3-(1-methylpyrrolidin-2-ylidene)-3H-indole (5): we have examined its crystal structure, ${ }^{9}$ its UV spectrum and basicity ${ }^{10}$ (it is a remarkably strong base, $\mathrm{p} K_{\mathrm{a}} 10.6$, which can be compared to the $\mathrm{p} K_{\mathrm{a}}$ of $4 \mathrm{a}$-methyl-1,2,3,4-tetrahydro-4a $H$-carbazole, a simple indolenine, of 3.6), and its intriguing reactivity with 1,3 -diketones, ${ }^{11,12}$ and malonates. ${ }^{13,14}$ Our continuing interest involves using alternatives to 1-methyl-2-pyrrolidinone in Vilsmeier-type reactions with indoles. Thus we came to use 1-cyclohexyl-2-pyrrolidinone $(\mathbf{8})$ in reaction with phosphoric trichloride and indole.

When 1-cyclohexyl-2-pyrrolidinone (8) was was employed in a standard Vilsmeier process, using $\mathbf{8}$ as both solvent and reactant (as in the standard sequence with DMF) and after diluting the final reaction mixture with water, a white precipitate was formed and was filtered off $(25 \%$ yield) leaving a clear aqueous solution. The solid proved to be the hydrochloride of 3-(1cyclohexylpyrrolidin-2-ylidene)-3H-indole $(\mathbf{9} . \mathrm{HCl})$ as a dihydrate (X-ray crystallography), the characteristic UV absorption (cf. reference 9), the absence of carbonyl stretching in the IR, and its structure determination by X-ray crystallography (Figures 1 and 2) were definitive. 


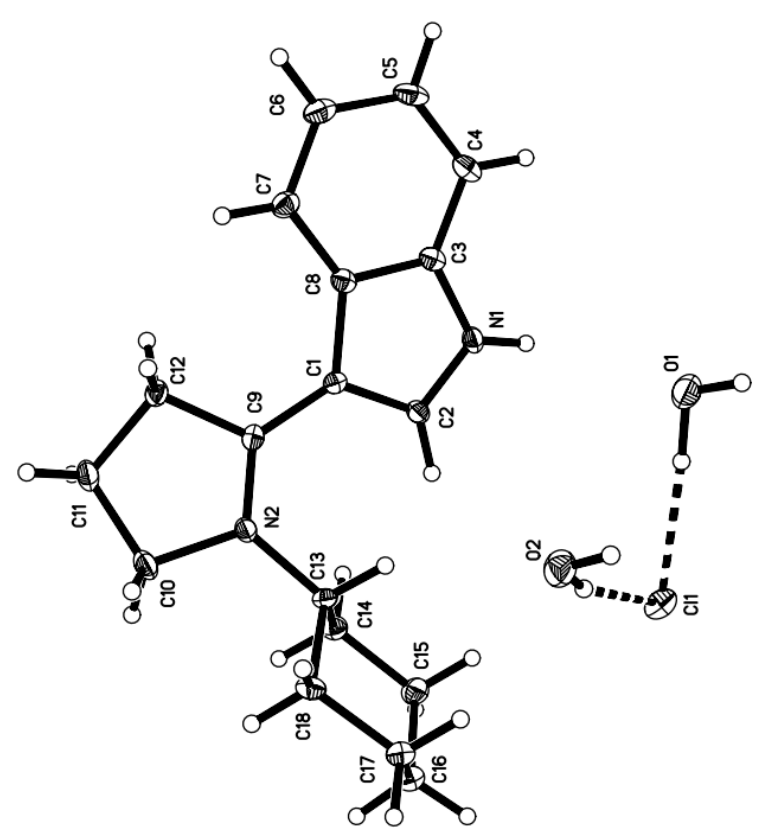

Figure 1. ORTEP representation of $9 . \mathrm{HCl} .2 \mathrm{H}_{2} \mathrm{O}$ showing the relative location of the water molecules and the chloride anion and the atom numbering system.

When the clear aqueous solution was made basic by the addition of sodium hydroxide at room temperature, a solid was formed, filtered off ( $68 \%$ yield) and purified - it proved to be the ketone (10) resulting from ring opening. The principal evidences for this were the conjugated carbonyl stretching at $1624 \mathrm{~cm}^{-1}$, the ${ }^{13} \mathrm{C}$ NMR signal for carbonyl carbon at $\delta 201.4$, the typical 3-acylindole UV absorption, and the observation of an indolic N-hydrogen ${ }^{1} \mathrm{H}$ NMR signal at 10.25 .

The free 3-(1-cyclohexylpyrrolidin-2-ylidene)-3H-indole base (9) could be obtained by very careful neutralization of its hydrochloride salt: this was achieved by dissolving the salt in water, cooling the solution to $-5{ }^{\circ} \mathrm{C}$, slow addition of aqueous $\mathrm{NaOH}$ precooled to $-5{ }^{\circ} \mathrm{C}$ till the $\mathrm{pH}$ reached 8 , all the while with vigorous stirring, then rapid extraction with pre-cooled $\mathrm{CHCl}_{3}$, drying of the extract and evaporation. The overall situation is summarized in Scheme 4. 


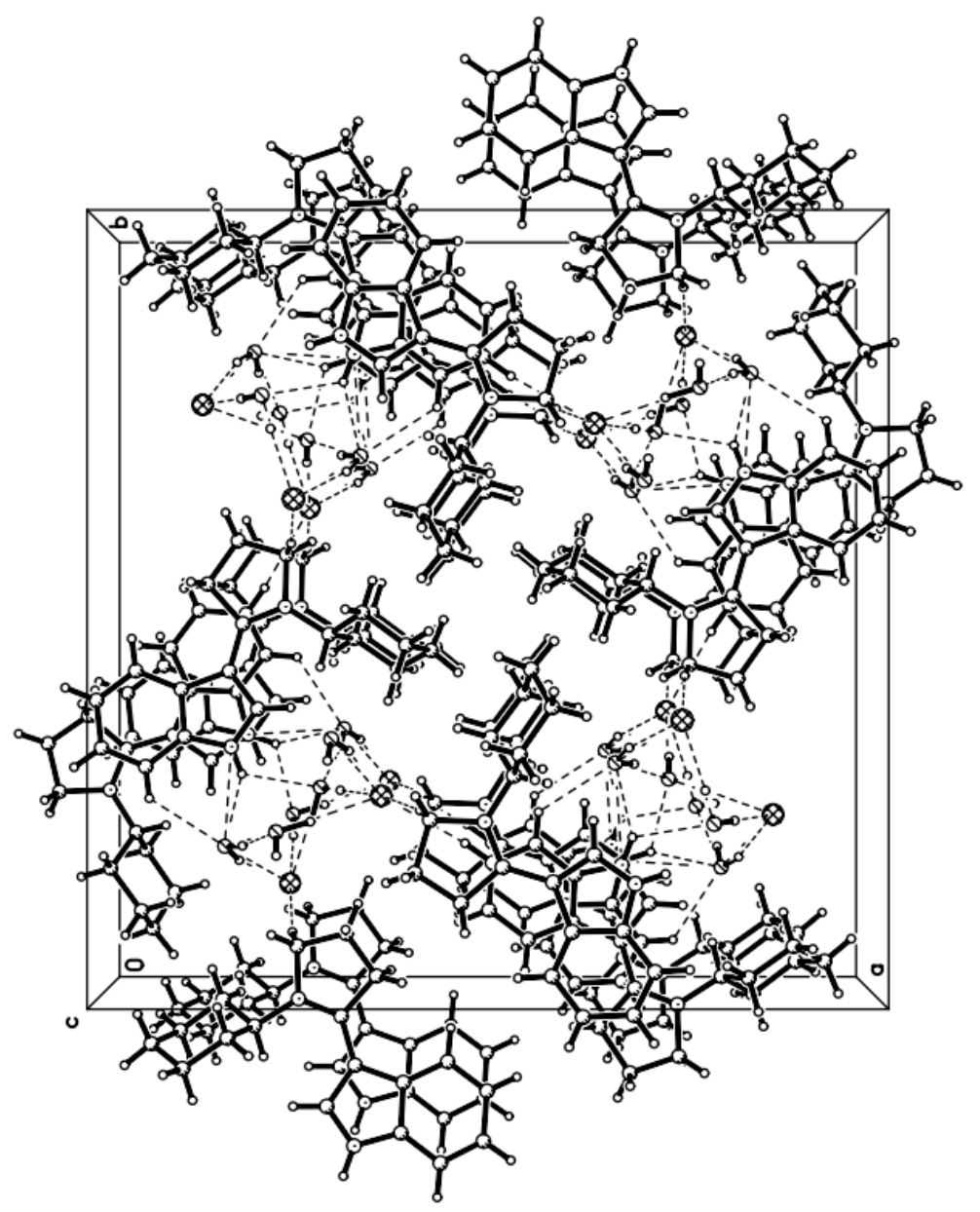

Figure 2. Viewed along the c axis the crystal packing generates columns of $\mathbf{9} . \mathrm{H}^{+} \mathrm{H}$-bonded together by columns of water and chloride.

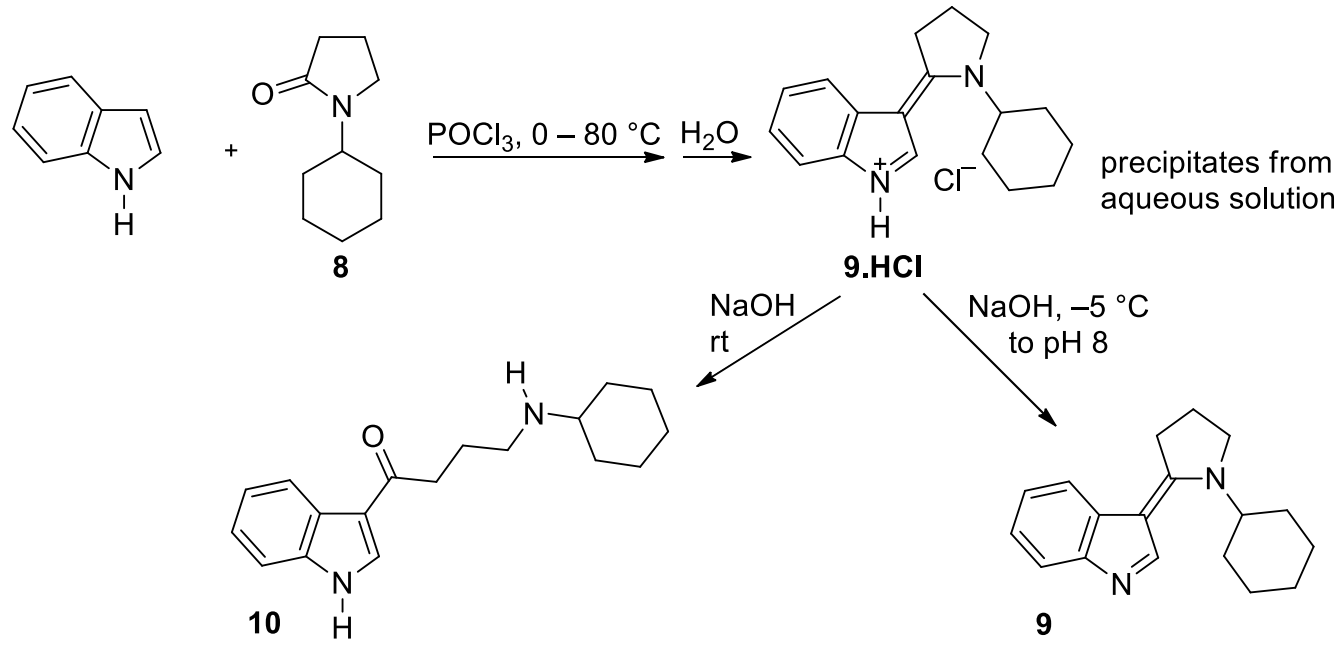

Scheme 4 
The structure of $9 . \mathrm{HCl} \cdot 2 \mathrm{H}_{2} \mathrm{O}$ determined by X-ray analysis (see Figures 1 and 2, and Supplementary Information for details) shows the conjugated system (linked indole and pyrrolidine rings) to be essentially planar, the maximum distances above and below the least squares plane through all the atoms (excluding the cyclohexyl unit except the carbon linked to nitrogen) are $0.470 \AA$ for $\mathrm{C} 13$ and $0.497 \AA$ for C11. Additionally one can note the small values of the four possible dihedral angles around the exocyclic double bond, which links the indole and pyrrolidine moieties, at only $11.2^{\circ}, 13.0^{\circ}, 15.8^{\circ}$ and $17.5^{\circ}$. The extensive conjugation which resonance contributor 11 implies (Figure 3) (and which explains the strongly basic character noted $^{9}$ for $\mathbf{5}$ ) is reflected in the bond lengths shown on $\mathbf{1 1 .}$

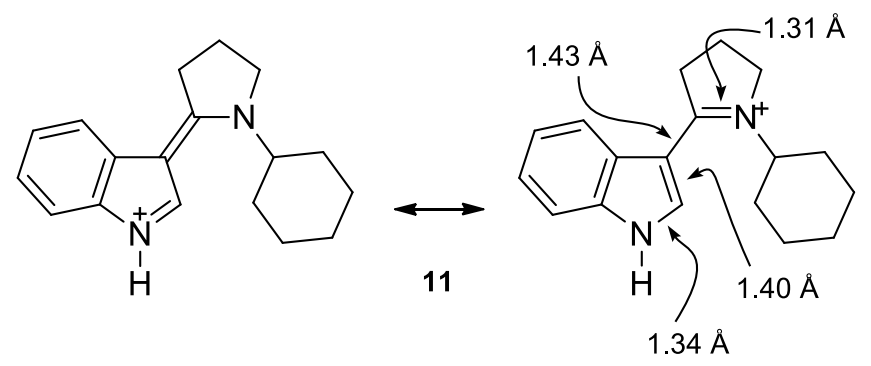

\section{Figure 3}

The cyclohexyl unit is twisted out of the plane of the rest of the molecule, no doubt to minimize adverse steric interactions; the average plane of the cyclohexyl unit is at a torsion angle of $66.93^{\circ}$ with respect to the average plane of the rest of the molecule. The nearest hydrogen (the hydrogen on the cyclohexyl carbon attached to nitrogen) to the imine hydrogen is at $2.00 \AA$.

\section{Experimental Section}

General. Melting points were determined on a Philip Harris C4954718 apparatus. Infrared spectra were recorded on a Thermo Nicolet (Nexus 670) Fourier transform (FT) infrared spectrometer, using sodium chloride cells and measured in $\mathrm{KBr}$ pellets. ${ }^{1} \mathrm{H}(300 \mathrm{MHz})$ and ${ }^{13} \mathrm{C}$ (75.5 MHz) NMR spectra were recorded on a Bruker 300 spectrometer in $\mathrm{CDCl}_{3}$ using TMS as the internal reference. Mass spectra were recorded on an Agilent 6890-N-Network-GC-system. The routine purification of reagents and solutions was carried out by standard laboratory procedures. ${ }^{15}$ Analytical thin-layer chromatography (TLC) was carried out with Merck silica gel $60 \mathrm{~F}_{254}$ aluminum sheets. Microanalyses were performed on a Leco Analyzer 932.

\section{3-(1-Cyclohexylpyrrolidin-2-ylidene)-3H-indolium hydrochloride dihydrate (9.HCl.2H $2 \mathrm{O})$.} To 1-cyclohexyl-2-pyrrolidinone $(6.69 \mathrm{~mL}, 0.04 \mathrm{~mol})$ cooled in an ice bath was added phosphoric trichloride $(2.40 \mathrm{~mL}, 0.026 \mathrm{~mol})$ with stirring during $30 \mathrm{~min}$, the temperature being 
kept at -10 to $0{ }^{\circ} \mathrm{C}$. The mixture was stirred for an additional $10 \mathrm{~min}$ then a solution of indole $(2.81 \mathrm{~g}, 0.024 \mathrm{~mol})$ in 1-cyclohexyl-2-pyrrolidinone $(6.69 \mathrm{~mL}, 0.04 \mathrm{~mol})$ was slowly added with stirring during $2 \mathrm{~h}$. The temperature rose to $45^{\circ} \mathrm{C}$ and the mixture was kept at this temperature for $1 \mathrm{~h}$ then heated at $80^{\circ} \mathrm{C}$ for $3 \mathrm{~h}$ and a solid separated. The mixture was cooled and then mixed with cold water $(100 \mathrm{~mL})$. A small amount of white solid was obtained besides the clear solution. The solid was filtered off and washed with cold water. Recrystallization from $\mathrm{PhMe} / \mathrm{CH}_{2} \mathrm{Cl}_{2}$ gave 3-(1-cyclohexylpyrrolidin-2-ylidene)-3H-indolium hydrochloride dihydrate (9. $\left.\mathrm{HCl} .2 \mathrm{H}_{2} \mathrm{O}\right)(1.2 \mathrm{~g}, 25 \%)$, m.p. $90-92{ }^{\circ} \mathrm{C} .{ }^{1} \mathrm{H}-\mathrm{NMR}\left(\mathrm{CDCl}_{3}\right) \delta(\mathrm{ppm}) 1.28-1.71\left(6 \mathrm{H}, \mathrm{m}, 3 \mathrm{CH}_{2}\right)$, 1.92-2.40 (6H, m, 3CH $), 3.69\left(2 \mathrm{H}, \mathrm{m}, \mathrm{CH}_{2}-\mathrm{C}=\right), 4.09\left(2 \mathrm{H}, \mathrm{m}, \mathrm{CH}_{2}-\mathrm{N}\right), 4.28(1 \mathrm{H}, \mathrm{m}, \mathrm{CH}-\mathrm{N})$, 7.23-7.81 $(4 \mathrm{H}, \mathrm{m}, \mathrm{Ar}), 7.98(1 \mathrm{H}, \mathrm{s}, \mathrm{HC}=\mathrm{N}), 14.09\left(1 \mathrm{H}, \mathrm{s}, \mathrm{NH}^{+}\right) .{ }^{13} \mathrm{C}-\mathrm{NMR}\left(\mathrm{CDCl}_{3}\right) \delta(\mathrm{ppm})$ $16.3,19.9,20.0,24.8,30.3,38.5,53.2,60.3,61.8,103.4,114.9,119.9,123.6,124.4,125.8$, 135.7, 137.4, 173.5. FT-IR (KBr, cm $\left.{ }^{-1}\right) v_{\max } 3411,2929,1591,1429,1229,753$. UV (EtOH, nm) $\lambda_{\max } 215,252,271,336$. MS (EI, $\left.70 \mathrm{ev}\right): \mathrm{m} / \mathrm{z}$ 184.93, 214.33, 254.40, 267.13.

Crystal data. A sample suitable for X-ray analysis was prepared by recrystallization from EtOH $/ \mathrm{H}_{2} \mathrm{O}$. Wavelength: $1.54178 \AA$; temperature: $100^{\circ} \mathrm{K}$; reflections collected/unique: 24773 / 3401; Completeness to $\theta=66.60^{\circ}: 99.5 \%$; space group: P-42(1)c; $\mathrm{a}=22.2242(4) \AA ; \mathrm{b}=$ $22.2242(4) \AA ; c=7.0062(2) \AA ; \alpha=90.00^{\circ} ; \beta=90.00^{\circ} ; \gamma=90.00^{\circ} ; V=3460.42(13) \AA^{3} ; Z=8$; $\mathrm{R}$ indices $[\mathrm{I}>2 \mathrm{~s}(\mathrm{I})]: \mathrm{R} 1=0.0442$, $\mathrm{wR} 2=0.1082$; $\mathrm{R}$ indices (all data) $\mathrm{R} 1=0.0461, \mathrm{wR} 2=0.1094$; the structure was solved with SHELXS-97 and refined with SHELXL-97. The crystallographic data data has been deposited at the Cambridge Crystallographic Data Centre and assigned the code number CCDC 885887.

4-(Cyclohexylamino)-1-(1H-indol-3-yl)butan-1-one (10). When the clear solution was made basic by the addition of $\mathrm{NaOH}(6 \mathrm{~g})$ in water $(30 \mathrm{~mL})$, a solid separated. The solid was filtered off and washed with water. Recrystallization from $n$-hexane gave 4-(cyclohexylamino)-1-(1Hindol-3-yl)butan-1-one (10) (4.63 g, 68\%), mp 112-113 ${ }^{\circ} \mathrm{C} .{ }^{1} \mathrm{H}-\mathrm{NMR}\left(\mathrm{CDCl}_{3}\right) \delta(\mathrm{ppm})$ 1.02-1.32 $\left(4 \mathrm{H}, \mathrm{m}, 2 \mathrm{CH}_{2}\right.$ overlapping with $1 \mathrm{H}$ of $\left.\mathrm{NH}\right), 1.60-1.80\left(4 \mathrm{H}, \mathrm{m}, 2 \mathrm{CH}_{2}\right), 1.89-2.02(4 \mathrm{H}, \mathrm{m}, 2$ $\left.\mathrm{CH}_{2}\right), 2.44-2.51(1 \mathrm{H}, \mathrm{m}, \mathrm{CH}), 2.78\left(2 \mathrm{H}, \mathrm{t}, J 7.2 \mathrm{~Hz}, \mathrm{CH}_{2}-\mathrm{N}\right), 2.90\left(2 \mathrm{H}, \mathrm{t}, J 7.2 \mathrm{~Hz}, \mathrm{CH}_{2}-\mathrm{C}=\mathrm{O}\right)$, 7.20-7.41 (5H, m, Ar), $10.25(1 \mathrm{H}, \mathrm{bs}$, indole $\mathrm{NH}) .{ }^{13} \mathrm{C}-\mathrm{NMR}\left(\mathrm{CDCl}_{3}\right) \delta(\mathrm{ppm}) 20.7,25.1,25.8$, 26.1, 30.2, 33.5, 49.8, 56.7, 58.5, 111.7, 119.4, 119.7, 121.9, 122.1, 123.2, 131.0, 149.0, 201.4. FT-IR $\left(\mathrm{KBr}, \mathrm{cm}^{-1}\right) v_{\max } 3431,3163,2926,1624,1439,1140,750$. UV (EtOH, nm) $\lambda_{\max } 211,241$, 261, 297. MS (EI, 70 ev) $\mathrm{m} / z$ 185.93, 261.13, 267.20, 284.80. Found C, 76.24; H, 8.47; N, 9.78. $\mathrm{C}_{18} \mathrm{H}_{24} \mathrm{~N}_{2} \mathrm{O}$ requires $\mathrm{C}, 76.02 ; \mathrm{H}, 8.51 ; \mathrm{N}, 9.85$.

3-(1-Cyclohexylpyrrolidin-2-ylidene)-3H-indole (9). 3-(1-Cyclohexylpyrrolidin-2-ylidene)$3 H$-indolium hydrochloride (9.HCl) was dissolved in water at $30-40{ }^{\circ} \mathrm{C}$ with stirring, then the solution was cooled to $-5{ }^{\circ} \mathrm{C}$ then very slowly, with efficient stirring, treated with pre-cooled sodium hydroxide at $-5{ }^{\circ} \mathrm{C}$ (until $\mathrm{pH}=8$ ). The mixture was shaken vigorously with pre-cooled chloroform and the layers rapidly separated. The chloroform layer was dried $\left(\mathrm{Na}_{2} \mathrm{SO}_{4}\right)$ and evaporated under reduced pressure. The residue was crystallized from $n$-hexane to give 3-(1cyclohexylpyrrolidin-2-ylidene)-3H-indole (9). m.p. 85-86 ${ }^{\circ} \mathrm{C} .{ }^{1} \mathrm{H}-\mathrm{NMR}\left(\mathrm{CDCl}_{3}\right) \delta(\mathrm{ppm}) 1.06-$ 
$1.61\left(6 \mathrm{H}, \mathrm{m}, 3 \mathrm{CH}_{2}\right), 1.89-2.10\left(6 \mathrm{H}, \mathrm{m}, 3 \mathrm{CH}_{2}\right), 3.35\left(2 \mathrm{H}, \mathrm{t}, J 7.5 \mathrm{~Hz}, \mathrm{CH}_{2}-\mathrm{C}=\right), 3.64(2 \mathrm{H}, \mathrm{t}, J=$ 7.2Hz, $\left.\mathrm{CH}_{2}-\mathrm{N}\right), 4.24(1 \mathrm{H}, \mathrm{m}, \mathrm{CH}-\mathrm{N}), 7.16-7.74(4 \mathrm{H}, \mathrm{m}, \mathrm{Ar}), 8.18(1 \mathrm{H}, \mathrm{s}, \mathrm{HC}=\mathrm{N}) .{ }^{13} \mathrm{C}-\mathrm{NMR}$ $\left(\mathrm{CDCl}_{3}\right) \delta(\mathrm{ppm})$ 20.7, 25.3, 30.2, 33.6, 35.7, 46.6, 49.8, 56.7, 58.5, 105.0, 119.5, 119.6, 121.8, 122.0, 131.0, 149.0, 151.1, 163.3. FT-IR (KBr, cm $\left.{ }^{-1}\right) v_{\max } 3166,2926,1624,1439,1138,748$. UV (EtOH, nm) $\lambda_{\max } 218,251,283,335$. Found C, 81.22; H, 8.39; N, 10.61. $\mathrm{C}_{18} \mathrm{H}_{22} \mathrm{~N}_{2}$ requires C, 81.16; H, 8.32; N, 10.52.

\section{Acknowledgements}

The authors are grateful to the University of Urmia for supporting of this work.

\section{References}

1. Vilsmeier, A.; Haack, A. Chem. Ber. 1927, 60, 119.

2. (a) Smith, G. F. J. Chem. Soc. 1954, 3842. (b) James, P. N.; Snyder, H. R. Org. Synth., Coll. 1963, (iv), 539.

3. e.g. pyrrole: (reference 2(a)). (a) Silverstein, R. M.; Ryskiewicz, E. E.; Willard, C. Org. Synth., Coll. 1963, (iv), 831. (b) de Groot, J. A.; Gorter-La Roy, G. M.; Koeveringe, J. A.; Lugtenburg, J. Org. Prep. Proced. Int. 1981, 13, 97.

4. Anthony, W. C. J. Org. Chem. 1960, 25, 2049.

5. (a) Rapoport, H.; Castagnoli, N. J. Am. Chem. Soc. 1962, 84, 2178. (b) Oishi, T.; Hirama, M.; Sita, L. R.; Masamune, S. Synthesis 1991, 789.

6. (a) Black, D. StC.; Bowyer, M. C.; Ivory, A. J.; Joliffe, K. A.; Kumar, N. Tetrahedron 1996, 52, 4687. (b) Black, D. StC.; Bowyer, M. C.; Kumar, N. Tetrahedron 1997, 53, 8573..

7. Youngdale, G. A.; Anger, D. G.; Anthony, W. C.; DaVanzo, J. P.; Greig, M. E.; Heinzelman, R. V.; Keasling, H. H.; Szmuszkovicz, J. J. Med. Chem. 1964, 7, 415.

8. Powers, J. C. J. Org. Chem. 1965, 30, 2534.

9. Helliwell, M.; Aghazadeh, M.; Baradarani, M. M.; Joule, J. A. Acta Cryst., Section E 2009, E65, o3114.

10. (a) Harris, M.; Joule, J. A. J. Chem. Res. (S) 1978, 25. (b) Harris, M.; Joule, J. A. J. Chem. Res. (M) 1978, 470.

11. (a) Bishop, D. I.; Al-Khawaja, I. K.; Joule, J. A. J. Chem. Res. (S) 1981, 361. (b) Bishop, D. I.; Al-Khawaja, I. K.; Joule, J. A. J. Chem. Res. (M) 1981, 4279.

12. Aghazadeh, M.; Baradarani, M. M.; Helliwell, M.; Joule, J. A. J. Med. Chem. 2011, 3, 98.

13. (a) Bishop, D. I.; Al-Khawaja, I. K.; Heatley, F.; Joule, J. A. J. Chem. Res. (S) 1982, 159. (b) Bishop, D. I.; Al-Khawaja, I. K.; Heatley, F.; Joule, J. A. J. Chem. Res. (M) 1982, 1766. 
14. (a) Al-Khawaja, I. K.; Beddoes, R. L.; Bishop, D. I.; Cernik, R. J.; Joule, J. A.; Mills, O. S. J. Chem. Res. (S) 1984, 296. (b) Al-Khawaja, I. K.; Beddoes, R. L.; Bishop, D. I.; Cernik, R. J.; Joule, J. A.; Mills, O. S. J. Chem. Res. (M) 1984, 2738.

15. Purification of Laboratory Chemicals, Armarego, W. L. F.; Perrin, D. D., Butterworth Heinemann, 1997. 